\title{
Learning by Doing? Partners Audit Experience and the Quality of Audit Services
}

\section{Josep García-Blandon ${ }^{a}$, Josep María Argilés-Bosch ${ }^{\mathrm{b}}$, Diego Ravenda ${ }^{\mathrm{c}}$}

a) IQS School of Management, Universitat Ramon Llull, Via Augusta 390, Barcelona, España. b) Department of Accounting, Universitat de Barcelona.

c) TBS Business School.

\section{${ }^{a}$ Corresponding author. E-mail address: josep.garcia@iqs.edu}

\section{A R T I C L E I N F O}

Article history:

Received 11 March 2019

Accepted 28 June 2019

Available online 1 July 2020

JEL classification:

M42

Keywords:

Individual auditor

Client-specific experience

Industry-specific experience

Generic audit experience

Audit quality

\begin{abstract}
A B S T R A C T
Despite evidence suggesting that specialised knowledge should be more relevant than generic knowledge to explain different levels of audit quality across individual auditors, no study to date has addressed the respective impacts of the industry-specific and the generic audit experience of audit partners on the quality of audit services. Our study investigates this issue in the Spanish audit market. We proxy audit quality by discretionary accruals and by the opinion of the audit report, and differentiate among client-specific experience, industry-specific experience and generic audit experience of individual auditors. As expected, our results show significantly higher audit quality when the client is audited by a partner with stronger industry-specific audit experience. Furthermore, we observe that neither client-specific experience nor generic audit experience of audit partners are significant determinants of the quality of audit services provided by these auditors. These results may have some interesting implications for audit firms. Therefore, whereas some prior studies on the related issue of industry specialization point out that specialised knowledge is more relevant than generic knowledge to explain the quality of audit services, our findings suggest that specialised knowledge is, in fact, the only type of knowledge that seems to matter.
\end{abstract}

(C)2020 ASEPUC. Published by EDITUM - Universidad de Murcia. This is an open access article under the CC BY-NC-ND license (http://creativecommons.org/licenses/by-nc-nd/4.0/).

Learning by Doing? La experiencia en auditoría del socio auditor y la calidad de los servicios de auditoría

\author{
RES U M EN
}

A pesar de la evidencia que sugiere que el conocimiento especializado debería resultar más relevante que el genérico para explicar diferentes niveles de calidad de auditoría asociados a los auditores individuales, ningún estudio hasta la fecha ha abordado el posible impacto diferencial de la experiencia genérica y específica en la calidad de los servicios de auditoría. Nuestro estudio investiga esta cuestión en el mercado de auditoría español. Aproximamos la calidad de la auditoría a partir de los ajustes de devengo discrecionales y la opinión del informe de auditoría; diferenciando entre experiencia específica con el propio cliente, experiencia sectorial y experiencia de auditoría genérica. Como se esperaba, los resultados muestran una mayor calidad de auditoría cuando el cliente es auditado por un socio con mayor experiencia en el sector de actividad del cliente. También observamos que ni la experiencia específica con el propio cliente, ni la experiencia genérica de auditoría del socio auditor son determinantes significativos de la calidad de los servicios de auditoría. Por otro lado, mientras que algunos estudios previos señalan que el conocimiento especializado resulta más relevante que el genérico para explicar la calidad de los servicios de auditoría, este trabajo sugiere que el conocimiento especializado es, de hecho, el único tipo de conocimiento que resulta relevante. Estos resultados pueden tener implicaciones interesantes para las firmas de auditoría.

(C2020 ASEPUC. Publicado por EDITUM - Universidad de Murcia. Este es un artículo Open Access bajo la licencia CC BY-NC-ND (http://creativecommons.org/licenses/by-nc-nd/4.0/). 


\section{Introduction}

The link between the audit experience of individual auditors and the quality of audit services provided by these auditors relies on the concept of expertise. Frensch \& Sternberg (1989, p. 158) define expertise as: "an ability acquired by practice to perform qualitatively well in a particular domain". In the auditing profession, the idea of "performing qualitatively well" is associated with the quality of audit services. Accordingly, expert auditors are expected to provide highquality audit services to their clients. Practical experience is generally regarded as a necessary input for the acquisition of knowledge (Libby \& Luft, 1993). This is very explicit in Frensch \& Sternberg's (1989) definition, when they refer to "acquired by practice". Therefore, if experience is a driver of expertise, we may wonder whether different types of experience could have different contributions to the creation of expertise.

The learning literature suggests that we may expect a differential impact of industry-specific and generic audit experience on the quality of audit services. As noted by Schilling et al. (2003), among others, learning curves used by psychologists to capture individual learning have reinforced the inference that learning is maximized through specialisation. Chi et al. (1982) and Glaser \& Chi (1988) stress the importance of domain-specific knowledge for the building up of expertise. Therefore, while it is widely accepted that specialised knowledge creates expertise, a much less empirically investigated issue is the potential contribution of generic knowledge. In this vein, Lapre et al. (2000) argue that experience gained in some types of projects could have no effects or even impede the learning process. Later on, Schilling et al. (2003) provide an interesting analysis of how related and unrelated task variation contribute to expertise by improving the learning rate. According to the authors, although both specialisation and task variety are relevant factors to explain productivity, the existing literature has yet to provide either explicit theoretical arguments or empirical evidence of their respective impacts on the learning-curve rate. Moreover, despite the commonly acknowledged efficiency advantages of specialisation, some papers on organizational learning have also examined the role of product or process variety (Fisher \& Ittner, 1999). It is worth mentioning Ellis' (1965) understanding of "learning to learn" in which he argues that the process of learning to learn implies that absorptive capacity may be improved even when the knowledge base possessed is not directly related to the knowledge base being acquired. Therefore, learning skills may be transferred across fields of knowledge that are organised or described in similar ways, even when the content of the knowledge is substantively different (i.e. clients belonging to different industries).

Focusing on the auditing literature, several studies have addressed the importance of the industry specialisation of audit firms (e.g. Ferguson et al., 2003; Kwon et al., 2007; Numan \& Willekens, 2012) and of audit partners (Chi \& Chin, 2011; Chin \& Chi, 2009; Garcia-Blandon \& Argiles-Bosch, 2018; Goodwin \& Wu, 2014; Zerni, 2012) as drivers of the quality of audit services. Accordingly, if specialised and generic knowledge are expected to contribute differently to the building up of expertise, the distinction between industry-specific and generic audit experience becomes relevant.

This study is motivated by the growing attention in the literature about the role and characteristics of audit partners to explain the quality of audit services. Bedard (2012) argues that the interest of scholars in this issue is a natural step in a progression from global audit firm networks to local offices. According to Knechel (2000), audit quality ultimately depends on the individual auditor judgments. Similarly, some authors point out the relevance of some personal characteristics of individual auditors (i.e. audit style, educational background and prior experience in large international audit firms) as determinants for the quality of audit services (e.g. Gul, Wu \& Yang, 2013; Knechel et al., 2015). However, this interest goes beyond the confines of academia, since many countries (including the US and EU member states) currently require the mandatory rotation of the audit partner after a specified number of years auditing a client. In May 2016, the Public Company Accounting Oversight Board adopted new regulations requiring the public disclosure of the individual audit partner responsible for each public company audit (Reid \& Youngman, 2017). In Spain, the first audit law, enacted in 1988, required the signature of the lead audit partner in the audit report. This requirement has been maintained in the subsequent reforms of the audit law. In the current audit law endorsed in 2015, the obligation of signature by the lead audit partner is explicitly recognized in Article 5.

Nevertheless, despite a significant increase in the number of studies which examine the influence of individual auditors on the quality of audit services, the specific issue of how the audit experience of partners contribute to audit quality has received very little attention. As the main exception, Chi et al. (2017) investigate this issue in the context of the Taiwanese audit market. The authors focus on the differences between pre-client and client-specific experience, concluding that both forms of audit experience improve audit quality, and that pre-client experience is positively associated with audit quality during the early years of the audit engagement, but not in the later years.

We continue Chi et al. (2017) line of research and investigate the relationship between partners audit experience and audit quality in the Spanish audit market for the research period between 2005 and 2013. Our study utilises discretionary accruals and the opinion of the audit report as the proxies for audit quality. However, whereas Chi et al. (2017) focus the attention on the different impact of pre-client and clientspecific experience, our main interest is on the respective contributions of the industry-specific and the generic audit experience of audit partners on the quality of audit services. Our approach is that when an auditor audits a client, let's say, in the construction sector, his/her audit experience is given by the total number of clients the auditor has audited in the past. However, part of this audit experience has been gained with clients in the construction sector (industry-specific experience), and part of it with clients in other sectors (generic audit experience). Following the conclusions of scholars in the psychological learning field (e.g. Chi et al., 1982; Glaser \& Chi, 1988), we understand that for the auditing of a client in the construction sector, the experience of the auditor with other construction firms is more relevant that, for example, the experience with financial institutions. We intend to contribute to the literature on the role of the individual auditor for the quality of audit services, in two main ways. First, by extending the work of Chi et al. (2017). It should be noted that, as Bedard (2012) points out, the importance of the professional audit environment to understand how individual auditors affect audit quality makes it difficult to generalize results. In this regard, as Chi et al. (2017), we provide evidence of the different contribution of pre-client and clientspecific audit experience to audit quality; yet, the most interesting feature of our study is the investigation of the respective contribution of industry-specific and generic audit experience. Secondly, whereas the results of most previous stud- 
ies on partners' industry specialisation indicate that industryspecific experience is more important than generic experience to explain the quality of audit services (e.g. Chi \& Chin, 2011; Zerni, 2012), these studies cannot explain whether or not generic audit experience is still relevant. Moreover, these papers justify the link between industry specialisation and audit quality on the fact that more specialised partners are expected to be more expert auditors. Nevertheless, industry specialisation might be only a poor proxy for expertise, mainly because the industry-specialisation variables used in these studies ignore the whole audit career and acquired experience of the auditor (see for example, the recent study of Garcia-Blandon \& Argiles-Bosch, 2018, also in the context of the Spanish audit market). ${ }^{1}$ Regarding prior studies on partner's industry specialization, our approach takes into account the whole audit career of audit partners (and not only a single specific year), and allows to understand whether generic audit experience is important or not. Beyond the audit field, this study intends to contribute to the existing literature on expertise, as it provides evidence of how specialised and generic knowledge impact the quality of complex services.

In anticipation of our results, we provide evidence that partner's industry-specific experience does enhance the quality of audit services. However, neither client-specific experience nor generic audit experience show any significant relationship with audit quality. Therefore, similar to Chi et al. (2017), we also find that pre-client audit experience contributes to higher audit quality; yet when we differentiate between industry-specific and generic audit experience, only the former appears to be relevant. Additionally, unlike Chi et al. (2017), our results do not indicate any significant relationship between client-specific experience and audit quality. These differences highlight the importance of the current professional audit environment to fully understand the impact of individual auditors on audit quality (Bedard, 2012), and stress the difficulties for generalizing results. The remaining body of the paper is structured as follows. The next section discusses previous literature, developing and formulating our hypotheses. The third section shows the design of the empirical research and the selection of the sample. Results are presented and discussed in section four. Finally, in the last section, conclusions are drawn, and the implications and limitations of this research are discussed.

\section{Background and Hypothesis Development}

This section discusses the results of prior studies and develops the hypotheses, by distinguishing three levels of audit experience: client-specific, industry-specific and generic audit experience.

\subsection{Client-Specific Experience}

According to the discussion in the introductory section, if expertise is mainly achieved through highly specific knowledge (Patel \& Groen, 1991), when auditing a client, the most obvious source of specific knowledge is the experience with this client in the past. However, according to the classical definition of audit quality by DeAngelo (1981), as the joint probability that an auditor will both detect and report material misstatements, although client-specific knowledge should

\footnotetext{
${ }^{1}$ According to these papers, an auditor acting as a signing partner for the very first year of his/her career and with only two clients, but both in the same industry, might be seen as more of an expert than another partner with more than 20 years of experience as a signing auditor and having audited more than 50 clients in different industries.
}

enhance the auditor's ability to detect misstatements, its independence might also be lower when the auditor has been auditing the client for a long period (Mautz \& Sharaf, 1961). Therefore, the a priori impact of client-specific experience on audit quality could be either positive or negative. In the US case, Manry et al. (2008) observe that audit quality, proxied by discretionary accruals, is positively and significantly associated with the number of years the client has been audited by the same partner. The available evidence for Taiwan is mixed, as Chen et al. (2008) and Chi et al. (2017) find higher audit quality in longer partner tenures, although Chi \& Huang (2005) observe that audit quality first increases with partner tenure but later declines. Evidence for the Australian audit market supports lower audit quality in longer tenures with the client. Fargher et al. (2008) observe lower (higher) manager's accounting discretion (audit quality) in the initial years of tenure of a new audit partner of the same firm, while Carey \& Simnett (2006) and Ye et al. (2011) report that longtenured partners are less likely to issue going-concern modified reports to financially distressed clients, thus showing lower independence. For the Spanish audit market, GarciaBlandon \& Argiles-Bosch (2017) do not support that longer tenures with a client involve significantly different levels of audit quality. As from a theoretical lens, client-specific knowledge could either enhance (through a "competence effect") or erode (through an "independence effect") audit quality, and given the inconclusive empirical evidence, we do not anticipate the sign of the effect. Therefore, we pose the first hypothesis of this study (H1) in the null form, as follows:

Hypothesis 1: The client-specific audit experience of individual auditors will not have a significant impact on audit quality.

\subsection{Industry-Specific Experience}

According to the learning-by-doing through experience framework (e.g. Ackerman, 1987; Ericsson et al., 1993), when auditing a client, the most valuable source of knowledge (apart from the very specific knowledge of this client) should be the experience gained through the auditing of similar clients. Following prior studies, we define client similarity as clients who belong to or are within the same industry. While previous literature has not examined the relationship between partners' industry-specific audit experience and audit services quality, a few studies have addressed the related issue of partners' industry specialisation (Chi \& Chin, 2011; Chin \& Chi, 2009; Garcia-Blandon \& Argiles-Bosch, 2018; Goodwin \& Wu, 2014; Nagy, 2014; Zerni, 2012). The main differences among these studies are the country-specific focus and investigation (US: Nagy, 2014; Taiwan: Chi \& Chin, 2011 and Chin \& Chi, 2009; Sweden: Zerni, 2012; Australia: Goodwin \& Wu, 2014; and Spain: Garcia-Blandon \& ArgilesBosch, 2018), and the proxy for the quality of audit services (the restatement of financial statements: Chin \& Chi, 2009; discretionary accruals and the opinion of the audit report: Chi \& Chin, 2011 and Garcia-Blandon \& Argiles-Bosch, 2018; and fees for audit services: Goodwin \& Wu, 2014; Nagy, 2014; Zerni, 2012). These articles tend to support that industry specialisation does enhance audit quality.

Chin \& Chi (2009) find a negative relationship between industry specialisation and the likelihood of accounting restatements in Taiwan, and thus, having a positive effect on audit quality. Still for Taiwan, Chi \& Chin (2011) observe that clients of industry specialists' auditors are more likely to receive a modified opinion (higher audit quality). For Sweden, Zerni (2012) conclude that industry specialisation is regarded as 
a differentiation strategy in terms of audit quality as proxied by audit services fees. In the same way, Goodwin \& Wu (2014) and Nagy (2014) find that the industry specialisation of individual auditors demands a fee premium in the US and Australian audit markets, respectively. Nevertheless, in some cases, the support in favour of industry specialisation is less clear. Hence, the negative association between partner industry specialisation and discretionary accruals reported in Chi \& Chin (2011) is significant only at marginal levels. Similarly, Garcia-Blandon \& Argiles-Bosch (2018) do not find any significant relationship between industry specialisation and audit quality in the Spanish audit market, as neither the levels of discretionary accruals nor the opinion of the audit report are significantly affected by the level of industry specialisation of individual auditors. It should be noted that the lack of significant results in Chi \& Chin (2011) or Garcia-Blandon \& Argiles-Bosch (2018) does not necessarily indicate that industry experience is irrelevant in terms of audit quality, but simply that it is not more relevant than generic audit experience.

Based on the psychological literature on expertise (e.g. Chi et al., 1982; Glaser \& Chi., 1988), we expect industry knowledge to have a positive impact on the quality of audit services. Moreover, unlike client-specific experience, industryspecific experience does not involve any potentially negative effects on the independence dimension of audit quality, and most prior studies have shown a positive relationship between industry specialisation and audit quality. Therefore, we pose the second hypothesis (H2) of this study as follows:

Hypothesis 2: The industry-specific audit experience of individual auditors will have a positive and significant impact on audit quality.

This study uses two labels ("subsector" and "sector") to account for industry-specific experience. Clients belonging to the same subsector are expected to show stronger similarities compared to those who belong to the same sector but to different subsectors. This twofold definition of industry should provide a detailed picture of the relative importance of specialised and generic knowledge as drivers of the quality of audit services. According to the aforementioned discussion, we expect stronger effects for industry-specific experience when industry is defined at the subsector level.

\subsection{Generic Audit Experience}

Patel \& Groen's (1991) study of expertise differentiates between generic and highly specific knowledge. Although specific knowledge is a necessary condition to achieve the level of expert, for lower levels of expertise (i.e. sub-expert level) generic knowledge is sufficient. Schilling et al. (2003) point out that varied prior learning might also enhance, or at least not negatively impact, the future learning rate. The reason is that prior knowledge (not necessarily specific knowledge) confers an ability to recognize the value, assimilation and application of new information (Cohen \& Levinthal, 1990). As Schilling et al. (2003, p. 44) remark: "Psychology studies of individual learning have demonstrated that related task variation (varying the content or context of the task) may enhance the learning process through facilitating the development of more abstract principles (or"schema") related to a general class of tasks". The auditing of clients from different industries provides, in our view, a meaningful example of related task variation.

We have not found any empirical studies on the importance of generic audit experience for the quality of the audit services provided by individual auditors. Besides, the few papers that have concluded that specialised knowledge contributes more to expertise than generic knowledge (Chi \& Chin, 2011; Chin \& Chi, 2009; Goodwin \& Wu, 2014; Nagy, 2014; Zerni, 2012) do not explain whether generic knowledge still contributes to expertise. Nevertheless, the results of Wang et al. (2015) for Sonu et al. (2016) for Korea and Chi et al. (2017) for Taiwan can shed some light on this issue. While these articles report a positive and significant relationship between the length of a partner's audit experience and audit quality, ${ }^{2}$ none of them differentiate between industryspecific and generic audit experience. Although there is no direct evidence of the impact of generic experience on expertise, given that partners with longer audit careers are expected to show stronger generic audit experience, the evidence reported by these articles suggests a positive and significant relationship between generic audit experience and the quality of audit services. Accordingly, we pose the third and last hypothesis of this study (H3) as follows:

Hypothesis 3: The generic audit experience of individual auditors will have a positive and significant impact on audit quality.

Following our previous discussion, we expect a weaker effect on audit quality for generic audit experience than for industry-specific experience.

\section{Research Design and Sample Selection}

\subsection{Research Design}

In line with previous related studies, we utilise the client's level of discretionary accruals and the opinion of the audit report as the proxies for the quality of audit services. In the first case, we assume that clients of high-quality auditors will manipulate less financial statement, and thus will present lower levels of discretionary accruals (Carey \& Simnett, 2006; Chi et al., 2017). As for the opinion of the audit report, similar to prior studies (e.g. Carey \& Simnett, 2006; Chi \& Chin, 2011), a lower propensity to issue a qualified report to a client who deserves it is considered as an indicator of weak auditor independence and, therefore, of lower audit quality.

\subsubsection{Analysis conducted with discretionary accruals}

The first empirical analysis is conducted with discretionary accruals computed as the residuals of Eq. (1) below, which represents Dechow et al. (1995) version of Jones' (1991) model:

$$
\begin{array}{r}
\left.T A_{t} / A_{t-1}=\alpha_{1}\left(1 / A_{t-1}\right)+\alpha_{2}\left(\left(\Delta R E V_{t}-\Delta R E C_{t}\right) / A_{t-1}\right)\right)+ \\
\alpha_{3}\left(P P E_{t} / A_{t-1}\right)+\varepsilon_{t}
\end{array}
$$

where:

$T A_{t}$ is total accruals in year $t$;

$\triangle R E V_{t}$ is revenues in year $t$ less revenues in year $t-1$;

$\triangle R E C_{t}$ is net receivables in year $t$ less net receivables in year $t-1$;

$P P E_{t}$ is gross property plant and equipment at the end of year $t$;

$A_{t-1}$ is total assets at the end of year $t-1$;

${ }^{2}$ Wang et al. (2015) and Chi et al. (2017) define experience by the cumulative number of years from the partner's first year as signing partner for any company and Sonu et al. (2016) by the length of an audit partner's experience as a certified public accountant. 
$\alpha_{1}, \alpha_{2}$ and $\alpha_{3}$ are the parameters to be estimated; and

$\varepsilon_{t}$ is the error term.

Unlike most prior studies which conduct cross-sectional estimations of Jones model by industry, we follow Mora \& Sabater's (2008) approach of industry-panel estimations of the model. Our decision is based on the relatively low number of firms per year and industry in our sample, a usual situation in international settings (Francis \& Wang, 2008). Subsequently, we propose a model with the absolute value of discretionary accruals as the dependent variable, and with our variables of interest measuring audit experience and the usual control variables in the literature (e.g. Carey \& Simnett, 2006; Chi \& Chin, 2011; Chi et al., 2017; Garcia-Blandon \& Argiles-Bosch, 2018) as the independent variables. The model we propose is shown by Eq. (2) below.

$$
\begin{gathered}
\text { DACCRABS }_{i, t}=\beta_{0}+\beta_{1} \text { EXPERIENCE }_{i, t}+\beta_{2} \text { ASSETS }_{i, t}+ \\
\beta_{3} \text { AGE }_{i, t}+\beta_{4} \text { CASHFLOW }_{i, t}+\beta_{5} \text { LAGACCR }_{i, t}+ \\
\beta_{6} \text { DEBT }_{i, t}+\beta_{7} \text { GROWTH Hi,t }_{i, t}+\beta_{8} \text { TENURE }_{i, t}+ \\
\beta_{9} \text { CIMPRT }_{i, t}+\beta_{10} \text { EXPERTF }_{i, t}+\beta_{11} \text { EXPERTP P P P }_{i, t}+ \\
\beta_{12} \text { BIG }_{i, t}+\text { fixed effects }_{i, t}+\mu_{i, t}
\end{gathered}
$$

where,

Dependent variable:

DACCRABS: discretionary accruals obtained as the residuals of the estimation of Eq. (1), in absolute values.

\section{Variable of interest (EXPERIENCE):}

We conduct four sequential estimations of Eq. (2), one with each definition of EXPERIENCE:

CLIENTEXP: number of consecutive audit reports of the same client signed by the partner until the current year;

SUBSECTOREXP: number of audit reports of companies belonging to the client's subsector (excluding the client) signed by the partner during his/her audit career until the current year;

SECTOREXP: number of audit reports of companies in the client's sector (excluding the client and the client's subsector) signed by the partner during his/her audit career until the current year; and

GENERICEXP: number of audit reports of companies not belonging to the client's sector signed by the partner during his/her audit career until the current year.

For the purposes of this research, we follow the industry classification scheme provided by the Madrid Stock Exchange, which includes six main sectors and 28 subsectors. The definition of industry in prior research on partners' industry specialisation corresponds to the definition of subsector used in this paper (i.e. Chi \& Chin, 2011 consider 27 industries). As discussed in the former section, we include two variables for measuring the impact of industry-specific experience (SUBSECTOREXP and SECTOREXP), and an additional variable for generic audit experience (GENERICEXP).

Control variables:

ASSETS: logarithm of firm's total assets;
$A G E$ : logarithm of the number of years the client has been listed by the supervisor of the Spanish stock market;

CASHFLOW: cash flow from operations on total assets;

LAGACCR: total accruals of the prior year on total assets;

$D E B T$ : firm's liabilities on total assets;

GROWTH: change in total assets regarding the previous year;

TENURE: logarithm of the number of years of tenure with the audit firm;

CIMPRT: total assets of the client divided by the sum of total assets of all clients audited by the audit partner in year $\mathrm{t}$;

EXPERTF: 1 if the company is audited by the lead audit firm in its industry (defined at the subsector level) in a year, and 0 otherwise;

EXPERTP:1 if the company is audited by the lead audit partner in its industry (defined at the subsector level) in a year, and 0 otherwise; and

BIG4: 1 if the firm is audited by a Big 4 auditor and 0 otherwise.

The model also includes industry and year fixed effects

The form of measuring the experience of the auditor constitutes a main difference between this study and previous works (Chi et al., 2017; Sonu et al., 2016; Wang et al., 2015). Wang et al. (2015) and Chi et al. (2017) define the audit experience by the number of years between the first audit report signed by the partner and the current year, and Sonu et al. (2016) by the number of years between the first year of the auditor registered as a certified public accountant (CPA) and the current year. In our view, both definitions are potentially problematic. On the one hand, because, as Sonu et al. (2016, p. 15) explicitly acknowledge: "our audit experience variable is prone to a measurement error, as it is possible that a CPA works for several years in auditing industry, moves to an investment bank, comes back to auditing industry, and finally becomes an audit partner". According to Sonu et al. (2016) definition of experience, a partner with minimal or even no real experience as a signing auditor may be labelled as a highly experienced auditor. Moreover, for all audit partners, every year registered as a CPA counts the same, no matter if he/she has audited one or ten clients. These problems also affect, for the most part, the definition of experience used by Chi et al. (2017) and Wang et al. (2015). Conversely, our measurement of experience allows to overcome these shortcomings as it is based on the number of clients that each audit partner has audited.

Next, we discuss the expected effects of the control variables in Eq. (2). We include ASSETS because larger firms are expected to present higher levels of audit quality and thus, less discretionary accruals (Watts \& Zimmerman, 1986). With $A G E$, we intend to capture the relationship between accruals and the firm's life cycle (Anthony \& Ramesh, 1992; Healy, 1996). Following Myers, Myers \& Omer (2003) and Carey \& Simnett (2006), among others, CASHFLOWS aims to capture a positive relationship between operating cash flows and firm performance (Frankel et al., 2002). Similar to Chi \& Chin (2011), we also control for LAGACCR due to the negative association of current accruals with previous-year accruals (Ashbaugh et al., 2003; Sloan, 1996). Following Becker, 
DeFond et al. (1998), among others, DEBT is in de model because the stronger incentives to manipulate earnings for firms with higher levels of debt. GROWTH intends to capture the relationship between accruals and firms' growth (Johnson et al., 2002). We do not anticipate the sign of the coefficient of TENURE as it might have opposite effects on each of the competence and independence dimensions of audit quality. Similar to Chi et al. (2017), we also include CIMPRT, EXPERTF and EXPERTP. Whereas CIMPRT aims to control for the importance of the client for the audit partner; EXPERTF and EXPERTP intend to capture the level of industry specialization of the audit firm and the audit partner, respectivelly. Finally, BIG4 is included to capture the positive higher-quality effect associated with Big 4 audit firms (Francis et al., 1999).

\subsubsection{Analysis conducted with the opinion of the audit report}

Together with discretionary accruals, the issuance of a qualified report to a client who deserves it constitutes another usual proxy for audit quality, as it is generally considered as an indicator of auditor independence. The Spanish regulation requires that the auditor express an opinion about the clients' financial statements, which can be: unqualified, qualified, unfavourable or disclaimer of opinion. For the purpose of this study, audit reports with qualified opinion, unfavourable opinion, disclaimer of opinion or with unqualified opinion but including paragraphs of emphasis expressing uncertainties, are jointly considered as audit reports with modified audit opinion (MAO). To examine the impact of the experience of the auditor on the quality of audit services as measured by the likelihood of issuing a qualified report, we utilise the logistic model given by Eq. (3), below. The model includes the opinion of the audit report (OPINION) as the dependent variable, and our variable of interest (EXPERIENCE) as well as the usual control variables used in the related literature (e.g. Carey \& Simnett, 2006; Chi \& Chin, 2011; GarciaBlandon \& Argiles-Bosch, 2018).

$$
\begin{gathered}
\text { OPINION }_{i, t}=\lambda_{0}+\lambda_{1} \text { EXPERIENCE }_{i, t}+\lambda_{2} \text { ASSETS }_{i, t} \\
+\lambda_{3} \text { AGE }_{i, t}+\lambda_{4} \text { DEBT }_{i, t}+\lambda_{5} \text { TENURE }_{i, t} \\
+\lambda_{6} \text { CIMPRT }_{i, t}+\lambda_{7} \text { EXPERT }_{i, t}+\lambda_{8} \text { EXPERTP }_{i, t} \\
+\lambda_{9} B I G 4_{i, t}+\lambda_{10} \text { PBANK }_{i, t}+\lambda_{11} \text { LAGLOSS }_{i, t} \\
+\lambda_{12} \text { LIQUIDITY }_{i, t}+\text { fixed effects }_{i, t}+\theta_{i, t}
\end{gathered}
$$

where,

\section{Dependent variable:}

OPINION: a dichotomous variable, which takes the value of 1 if the audit report has a MAO and 0 otherwise.

We utilise the same four specific variables for EXPERIENCE as in the former analysis with discretionary accruals (CLIENTEXP, SUBSECTOREXP, SECTOREXP and GENERICEXP). These variables have been already defined in Eq. (2). Moreover, as with Eq. (2), we perform four sequential estimations of Eq. (3), one for each definition of EXPERIENCE.

Control variables in Eq. (3) attempt to capture the incentives of the auditor to issue a qualified audit report. Most of them were also included in Eq. (2) (ASSETS, AGE, DEBT, TENURE, CIMPRT, EXPERTF, EXPERTP and BIG4). However, in this analysis, we also include:

PBANK: the probability of bankruptcy as captured by adjusted Zmijewski scores provided by Zmijewski (1984) with the weights proposed by Carcello et al. (1995);
LAGLOSS: 1 if the company has negative net income in the last two years and 0 otherwise; and

LIQUIDITY: current assets divided by current liabilities.

We include ASSETS (no sign prediction) as client's size could influence the willingness of the auditor to issue a qualified report. First, auditors may be more willing to issue qualified reports to large clients as these clients involve higher litigation costs (Lys \& Watts, 1994; Shu, 2000). However, higher accounting quality and more negotiation power might make modified opinions less likely for large clients (Myers et al., 2003). AGE (negative expected coefficient) is included because young firms face higher bankruptcy risk. Following the discussion of TENURE in Eq. (2), the effects of TENURE on the likelihood of a MAO in the audit report could be either positive or negative. We predict a negative coefficient for CIMPRT, as the audit partner may be more reluctant to issue a qualified report to a client when this client represents a larger share of the partner's portfolio of clients, and positive coefficient for EXPERTF and EXPERTP. As Carey \& Simnett (2006), among others, we include BIG4 (positive expected coefficient) to capture that Big 4 auditors may be more willing to issue qualified reports. Finally, $D E B T, P B A N K, L A$ GLOSS, and LIQUIDITY intend to capture the financial situation of the auditor client. Accordingly, we predict positive coefficients for DEBT, PBANK and LAGLOSS, as these variables are positively associated with financial distress (higher litigation risk for the auditor) and a negative coefficient for LIQUIDITY.

\subsection{Sample}

The sample for the empirical analysis comprises firms quoted in the Spanish stock market (continuous market) between 2005 and 2013. As it is usual in the related literature financial companies have been excluded from the sample. The information about individual auditors and audit firms is taken from the financial statements, made publicly available via the Spanish regulatory agency's website, Comisión Nacional del Mercado de Valores (CNMV). Capital IQ database is used for obtaining financial variables. Our variables accounting for auditor experience (CLIENTEXP, SUBSECTOREXP, SECTOREXP and GENERICEXP) were constructed with the information at the partner level available at CNMV registers. A limitation of CNMV registers is that the first year of available information is 1995. Thus, we are able to collect information about the audit experience of individual auditors only from 1995 onwards. The initial sample consists of 101 firms and, given the nine-year research period, by a maximum of 909 firm-year observations. However, we lost 62 firm-year observations because lack of data, and 49 because we removed from the sample those firm-year observations associated to audit firm changes. Hence, in the study conducted with discretionary accruals (model given by Eq. (2)), the final sample consists of 798 firm-year observations. In the model given by Eq. (3), the sample is further reduced by 36 observations due to lack of data, leading to a final sample of 762 observations.

Table 1 provides some descriptive statistics for the sample. Focusing on the variables of interest, we do not observe strong industry specialisation of individual auditors, as $G E N$ ERICEXP shows a larger mean than both variables accounting for industry-specific experience (SUBSECTOREXP and SECTOREXP). Moreover, results for CLIENTEXP indicate that auditor-client relationships last three years on average. On the other hand, figures for SUBSECTOREXP and SECTOREXP 
Table 1

Descriptive statistics for our dataset

\begin{tabular}{lccccc}
\hline \multicolumn{7}{c}{ Panel A (variables of interest) } \\
\hline VARIABLE & MEAN & ST. DEV. & Q1 & Q2 & Q3 \\
\hline CLIENTEXP & 3.43 & 2.01 & 2.00 & 3.00 & 5.00 \\
SUBSECTOREXP & 1.15 & 2.72 & 0.00 & 0.00 & 0.00 \\
SECTOREXP & 1.15 & 2.53 & 0.00 & 0.00 & 0.00 \\
GENERICEXP & 3.75 & 5.17 & 0.00 & 1.00 & 6.00 \\
\hline \multicolumn{7}{c}{ Panel B (control variables) } \\
\hline VARIABLE & MEAN & ST. DEV. & Q1 & Q2 & Q3 \\
\hline ASSETS & 6.85 & 1.79 & 5.53 & 6.67 & 8.08 \\
AGE & 2.65 & 0.64 & 2.30 & 2.94 & 3.09 \\
CASHFLOW & 0.06 & 0.14 & 0.02 & 0.06 & 0.11 \\
LAGACCR & -0.04 & 0.18 & -0.08 & -0.04 & 0.00 \\
DEBT & 0.67 & 0.29 & 0.52 & 0.67 & 0.79 \\
GROWTH & 1.49 & 6.15 & 0.93 & 1.05 & 1.17 \\
TENURE & 2.11 & 0.77 & 1.60 & 2.20 & 2.77 \\
CIMPRT & 0.74 & 0.36 & 0.45 & 1.00 & 1.00 \\
EXPERTF & 0.14 & 0.34 & 0.00 & 0.00 & 0.00 \\
EXPERTP & 0.54 & 0.50 & 0.00 & 1.00 & 1.00 \\
BIG4 & 0.91 & 0.28 & 1.00 & 1.00 & 1.00 \\
PBANK & -2.10 & 1.66 & -3.29 & -1.99 & -0.87 \\
LAGLOSS & 0.21 & 0.41 & 0.00 & 0.00 & 0.00 \\
LIQUIDITY & 1.44 & 1.31 & 0.91 & 1.18 & 1.59 \\
\hline
\end{tabular}

Variables of interest:

CLIENTEXP (experience of the auditor with the client): number of consecutive audit reports of the same client signed by the partner until the current year; SUBSECTOREXP (experience of the auditor in the client's subsector): number of audit reports of companies belonging to the client's subsector (excluding the client) signed by the partner during his/her audit career until the current year; SECTOREXP (experience of the auditor in the client's sector): number of audit reports of companies in the client's his/her audit his the auditor): number of audit reports of companies not belonging to the client's sector signed by the partner during his/her audit career until the current year. Control variables:

ASSETS (client's size): logarithm of firm's total assets; AGE (client's age): logarithm of number of years the client has been listed by the supervisor of the Spanish stock market; CASHFLOW (client's cash-flows from operations); cash flow from operations on total assets; LAGACCR (client's lagged accruals): total accruals of the prior year on total assets; DEBT (client's debt ratio): firm's liabilities on total assets; GROWTH (client's growth): change in total assets regarding the previous year; TENURE (audit firm tenure): logarithm of the number of years of tenure with the audit firm; CIMPRT (client's imporance): total assets of the client divided by the sum of total assets of all 1 if the company is audited by the lead audit firm in its industry (defined at subsector level) in a year, and 0 otherwise; EXPERTP (expert audit partner): 1 if the company is audited by the lead audit partner in its industry (defined at subsector level) in a year, and 0 otherwise; BIG4 (audit firm type): 1 if the firm is audited by a Big 4 auditor and 0 otherwise; PBANK (client's probability of bankruptcy): Zmijewski scores; LAGLOSS (client's lagged loss): 1 if the company has negative net income in the last two years and 0 otherwise; and LIQUIDITY (client's liquidity): current assets divided by current liabilities.

are rather similar. As for the control variables in Eq. (2), the most interesting results is extremely high level of concentration of the Spanish audit market for quoted companies by Big 4 audit firms. The correlation matrix (untabulated) shows the predicted significant relationships of discretionary accruals (DACCRABS) with ASSETS, AGE, CASHFLOW, LAGACCR, DEBT, GROWTH, TENURE and BIG4. However, the correlation with CIMPRT and EXPERTF is insignificant, and with EXPERTP is significant but with an unexpected positive sign. We also observe negative and significant correlations of discretionary accruals with all the variables measuring partner's experience, thus suggesting a positive impact of the audit experience on the quality of audit services. It also shows the expected high positive correlations among variables measuring experience, as partners with longer (shorter) audit careers tend to show higher (lower) levels of audit experience with the client, in the client's industry as well as generic audit experience. This fact supports our decision to perform sequential estimations of Eq. (2) and (3) with one measure of experience at a time. Finally, the correlation pattern of independent variables does not suggest serious multicollinearity in our dataset.

\section{Results of the Study}

\subsection{Analysis Conducted with Discretionary Accruals}

Table 2 shows the results of the sequential estimations of Eq. (2) with each measure of experience: CLIENTEXP (Model 1), SUBSECTOREXP (Model 2), SECTOREXP (Model 3) and GENERICEXP (Model 4). To minimize the incidence of outliers in our estimations, variables are winsorized at the top and bottom 1 percent of their respective distributions. In keeping with the panel structure of the dataset, panel data estimations are conducted. The Hausman test suggests the use of random effects models and, subsequently, the BreuschPagan Lagrange multiplier test supports the panel data approach over ordinary least squares regressions. As we detect heteroscedasticity and autocorrelation in the dataset, we estimate Eq. (2) with Prais-Wistein regression with heteroscedastic panels corrected errors. Even though the analysis of the covariance matrix does not suggest serious multicollinearity problems, we compute variance inflation factors (untabulated) to further discard the negative effects of multicollinearity on the estimates. As expected, the values of variance inflation factors do not indicate multicollinearity problems in the dataset (mean of 2.23 with a maximum value of 3.15 for LAGACCR).

Table 2 shows that all four estimations are significant at standard statistically levels. Focusing on the variables of interest measuring auditor experience, we report significant results only for SUBSECTOREXP ( $p$-value < 0.05) in Model 2 , with the predicted negative sign. Hence, partners with stronger audit experience in the client's subsector present higher levels of audit quality. Conversely, client-specific experience, experience in the client's sector (excluding the subsector), as well as generic audit experience do not seem to involve any significantly different levels of audit quality. These results support Hypothesis 1 (as it was posed in the null form) and Hypothesis 2 (though only when industry is defined at the subsector level). Conversely, Hypothesis 3 is rejected, as generic audit experience does not seem to have any significant impact on the quality of audit services.

As we discussed in the review of the literature section of the study, prior research on the impact of client-specific experience on audit quality has reported inconclusive results. However, the lack of significant effects of this type of audit experience observed here supports prior evidence for the Spanish audit market (Garcia-Blandon \& Argiles-Bosch, 2017). It should be noted, however, that Chi et al. (2017) find, not only that client-specific experience is an important driver of audit quality, but also that it dominates over pre-client audit experience. The differences between our results and Chi et al. (2017) highlight the importance of the current professional audit environment to understand the impact of individual auditors on audit quality (Bedard, 2012), and consequently, the difficulties of generalizing results. Regarding pre-client experience, Chi et al. (2017) conclude that it is positively associated with audit quality. However, they do not differentiate between industry-specific experience and generic audit experience. Therefore, our findings complement the results of Chi et al. (2017), as we observe that when auditing a client, the only relevant pre-client audit experience is the experience of the auditor in the client's industry.

Our findings can be also interpreted in the light of the lit- 
Table 2

The relationship between auditor experience and the quality of audit services as measured by discretionary accruals. Dependent variable: absolute discretionary accruals

\begin{tabular}{|c|c|c|c|c|c|}
\hline Variable & $\begin{array}{l}\text { Pred. } \\
\text { sign }\end{array}$ & Model 1 & Model 2 & Model 3 & Model 4 \\
\hline CLIENTEXP & ? (H1) & $\begin{array}{l}-0.000 \\
(-0.31)\end{array}$ & & & \\
\hline SUBSECTOREXP & - (H2) & & $\begin{array}{c}-0.02 \\
(-2.17)^{* *}\end{array}$ & & \\
\hline SECTOREXP & - (H2) & & & $\begin{array}{l}-0.001 \\
(-1.15)\end{array}$ & \\
\hline GENERICEXP & - (H3) & & & & $\begin{array}{l}-0.000 \\
(-0.39)\end{array}$ \\
\hline ASSETS & - & $\begin{array}{c}-0.006 \\
(-3.86)^{* * *}\end{array}$ & $\begin{array}{c}-0.006 \\
(-3.73)^{* * *}\end{array}$ & $\begin{array}{c}-0.006 \\
(-3.79)^{* * *}\end{array}$ & $\begin{array}{c}-0.006 \\
(-3.77)^{* * *}\end{array}$ \\
\hline AGE & - & $\begin{array}{c}-0.013 \\
(-2.43)^{* *}\end{array}$ & $\begin{array}{c}-0.013 \\
(-2.48)^{* *}\end{array}$ & $\begin{array}{c}-0.013 \\
(-2.45) * *\end{array}$ & $\begin{array}{c}-0.013 \\
(-2.41)^{* *}\end{array}$ \\
\hline CASHFLOW & - & $\begin{array}{c}-0.189 \\
(-4.98)^{* * *}\end{array}$ & $\begin{array}{c}-0.187 \\
(-4.93)^{* * *}\end{array}$ & $\begin{array}{c}-0.190 \\
(-4.95)^{* * *}\end{array}$ & $\begin{array}{c}-0.188 \\
(-4.91)^{* * *}\end{array}$ \\
\hline LAGACCR & - & $\begin{array}{c}-0.072 \\
(-1.65)^{*}\end{array}$ & $\begin{array}{l}-0.068 \\
(-1.55)\end{array}$ & $\begin{array}{l}-0.071 \\
(-1.63)\end{array}$ & $\begin{array}{l}-0.069 \\
(-1.59)\end{array}$ \\
\hline DEBT & + & $\begin{array}{c}0.042 \\
(2.43)^{* *}\end{array}$ & $\begin{array}{c}0.042 \\
(2.41)^{* *}\end{array}$ & $\begin{array}{c}0.042 \\
(2.44) * *\end{array}$ & $\begin{array}{c}0.042 \\
(2.42)^{* *}\end{array}$ \\
\hline GROWTH & + & $\begin{array}{c}0.017 \\
(3.50) * * *\end{array}$ & $\begin{array}{c}0.017 \\
(3.46)^{* * *}\end{array}$ & $\begin{array}{c}0.017 \\
(3.50)^{* * *}\end{array}$ & $\begin{array}{c}0.017 \\
(3.48)^{* * * *}\end{array}$ \\
\hline TENURE & $+/-$ & $\begin{array}{l}0.002 \\
(0.57)\end{array}$ & $\begin{array}{l}0.003 \\
(0.76)\end{array}$ & $\begin{array}{l}0.001 \\
(0.35)\end{array}$ & $\begin{array}{l}0.001 \\
(0.39)\end{array}$ \\
\hline CIMPRT & + & $\begin{array}{l}-0.009 \\
(-1.51)\end{array}$ & $\begin{array}{l}-0.008 \\
(-1.49)\end{array}$ & $\begin{array}{l}-0.008 \\
(-1.49)\end{array}$ & $\begin{array}{l}-0.009 \\
(-1.50)\end{array}$ \\
\hline EXPERTF & - & $\begin{array}{l}0.007 \\
(1.56)\end{array}$ & $\begin{array}{l}0.007 \\
(1.59)\end{array}$ & $\begin{array}{l}0.006 \\
(1.50)\end{array}$ & $\begin{array}{l}0.006 \\
(1.53)\end{array}$ \\
\hline EXPERTP & - & $\begin{array}{l}0.002 \\
(0.30)\end{array}$ & $\begin{array}{l}0.002 \\
(0.29)\end{array}$ & $\begin{array}{l}0.002 \\
(0.33)\end{array}$ & $\begin{array}{l}0.002 \\
(0.29)\end{array}$ \\
\hline BIG4 & - & $\begin{array}{c}-0.037 \\
(-2.94)^{* * *}\end{array}$ & $\begin{array}{c}-0.035 \\
(-2.80) * * *\end{array}$ & $\begin{array}{c}-0.036 \\
(-2.82)^{* * *}\end{array}$ & $\begin{array}{c}-0.037 \\
(-2.90)^{* * *}\end{array}$ \\
\hline Fixed effects & & YES & YES & YES & YES \\
\hline Constant & & $\begin{array}{c}0.234 \\
(8.86)^{* * *}\end{array}$ & $\begin{array}{c}0.230 \\
(8.79)^{* * *}\end{array}$ & $\begin{array}{c}0.234 \\
(8.89)^{* * *}\end{array}$ & $\begin{array}{c}0.233 \\
(8.85)^{* * *}\end{array}$ \\
\hline \# of observations & & 798 & 798 & 798 & 798 \\
\hline R-sq. & & 0.42 & 0.43 & 0.42 & 0.42 \\
\hline Wald-Chi sq. & & $226.09 * * *$ & $228.59 * * *$ & $229.84 * * *$ & $226.14^{* * *}$ \\
\hline
\end{tabular}

, , ${ }^{* *},{ }^{* * *}$ Statistical significance at $10 \%, 5 \%$ and $1 \%$, respectively.

CLIENTEXP (experience of the auditor with the client); SUBSECTOREXP (experience of the auditor in the client's subsector); SECTOREXP (experience of the auditor in the client's sector); GENERICEXP (generic audit experience of the auditor); ASSETS (client's size); AGE (client's age); CASHFLOW (client's cash-flows from operations); LAGACCR (client's lagged accruals) DEBT (client's debt ratio); GROWTH (client's growth); TENURE (audit firm tenure); CIMPRT (client's importance); EXPERTF (expert audit firm); EXPERTP (expert audit partner); and BIG4 (audit firm type).

erature on the importance auditor industry specialisation for the quality of audit services. Prior studies on this field generally conclude that industry specialisation has a positive impact on audit quality (Chi \& Chin, 2011; Chin \& Chi, 2009; Zerni, 2012). Therefore, the negative and significant coefficient on SUBSECTEXP in Model 2 is consistent with most prior studies on industry specialisation supporting that specialised knowledge is a driver of expertise in the audit sector. However, our approach based on the examination of the audit career of individual auditors presents important advantages compared to prior studies on industry specialisation. First, as these studies define industry specialisation based only on the current portfolio of clients of the partner, they ignore any audit experience gained by the auditor in the previous years. As Ittonen et al. (2015) point out, focusing only on the current year, thus ignoring all the previous audit experience of individual auditors makes it difficult to adequately capture audit partner's expertise. The results for SUBSECTOR combined with the lack of significance of $E X$ PERTP in all the estimations and with the findings of GarciaBlandon \& Argiles-Bosch (2018) study on partner's industry specialisation, also in the context of the Spanish audit market, showing no significant effects of industry specialization on audit quality, provides support for this view. These differences indicate that considering the whole audit career of the auditor provides a better proxy for expertise than focusing only on the current year. Secondly, the industry specialisation approach does not allow a proper assessment of the importance of generic audit experience as a determinant of audit quality. The reporting of a positive impact of industry specialisation on audit quality merely indicates that industryspecific experience is more relevant than generic audit experience. However, we do not know whether or not generic audit experience is still relevant. In this regard, our results do not only indicate that industry-specific experience is relevant for audit quality, but more interestingly in terms of the contribution to the audit literature, that it is the only type of audit experience that seems to matter.

Results for control variables are very much in line with our expectations. Hence, we report significant effects for ASSETS, AGE, CASHFLOW, DEBT, GROWTH and BIG4, in all cases in the predicted direction.

Table 3

The relationship between auditor experience and the quality of audit services as measured by discretionary accruals. Dependent variable: signed discretionary accruals

\begin{tabular}{lcccc}
\hline Variable & Model 1 & Model 2 & Model 3 & Model 4 \\
\hline CLIENTEXP & 0.001 & & & \\
& $(0.83)$ & & & \\
SUBSECTOREXP & & -0.001 & & \\
SECTOREXP & & $(-1.75) *$ & & \\
& & & -0.000 & \\
& & & $(-0.05)$ &
\end{tabular}

GENERICEXP

\begin{tabular}{|c|c|c|c|c|}
\hline \multirow{3}{*}{ ASSETS } & & & & \\
\hline & 0.002 & 0.002 & 0.002 & 0.002 \\
\hline & (1.19) & $(1.25)$ & (1.19) & (1.29) \\
\hline \multirow{2}{*}{ AGE } & -0.007 & -0.007 & -0.007 & -0.007 \\
\hline & $(-1.48)$ & $(-1.47)$ & $(-1.44)$ & $(-1.34)$ \\
\hline \multirow{2}{*}{ CASHFLOW } & -0.130 & -0.134 & -0.132 & -0.132 \\
\hline & $(-4.11)^{* * *}$ & $(-4.26) * * *$ & $(-4.17) * * *$ & $(-4.19) * * *$ \\
\hline \multirow[t]{2}{*}{ LAGACCR } & 0.709 & 0.707 & 0.707 & 0.708 \\
\hline & $(18.58)^{* * *}$ & $(18.58)^{* * *}$ & $(18.58)^{* * *}$ & $(18.61)^{* * *}$ \\
\hline \multirow{2}{*}{ DEBT } & 0.027 & 0.026 & 0.026 & 0.025 \\
\hline & $(1.92)^{*}$ & $(1.86)^{*}$ & $(1.86) *$ & $(1.83)^{*}$ \\
\hline \multirow{2}{*}{ GROWTH } & -0.012 & -0.012 & -0.012 & -0.012 \\
\hline & $(-1.86)^{*}$ & $(-1.87)^{*}$ & $(-1.86)^{*}$ & $(-1.88)^{*}$ \\
\hline \multirow{2}{*}{ TENURE } & -0.006 & -0.005 & -0.006 & -0.005 \\
\hline & $(-1.79)^{*}$ & $(-1.52)$ & $(-1.67)^{*}$ & $(-1.76) *$ \\
\hline \multirow{2}{*}{ CIMPRT } & -0.005 & -0.005 & -0.005 & -0.005 \\
\hline & $(-0.87)$ & $(-0.87)$ & $(-0.86)$ & $(-0.87)$ \\
\hline \multirow{2}{*}{ EXPERTF } & -0.004 & -0.004 & -0.004 & -0.004 \\
\hline & $(-0.79)$ & $(-0.77)$ & $(-0.81)$ & $(-0.82)$ \\
\hline \multirow{2}{*}{ EXPERTP } & 0.001 & 0.001 & 0.001 & 0.001 \\
\hline & $(0.12)$ & (0.13) & $(0.13)$ & $(0.10)$ \\
\hline \multirow{2}{*}{ BIG4 } & 0.021 & 0.022 & 0.021 & 0.022 \\
\hline & (1.64) & $(1.67)^{*}$ & $(1.60)$ & $(1.66)^{*}$ \\
\hline Fixed effects & YES & YES & YES & YES \\
\hline \multirow[t]{2}{*}{ Constant } & 0.014 & 0.015 & 0.016 & 0.015 \\
\hline & $(0.33)$ & $(0.36)$ & $(0.37)$ & $(0.35)$ \\
\hline \# of observations & 798 & 798 & 798 & 798 \\
\hline R-sq. & 0.61 & 0.61 & 0.61 & 0.61 \\
\hline Wald-Chi sq. & $775.28^{* * *}$ & $768.93 * * *$ & $768.49 * * *$ & $767.78^{* * * *}$ \\
\hline
\end{tabular}

CLIENTEXP (experience of the auditor with the client); SUBSECTOREXP (experience of the auditor in the client's subsector); SECTOREXP (experience of the auditor in the client's sector); GENERICEXP (generic audit experience of the auditor); ASSETS in the client's sector); GENERICEXP (generic audit experience of the auditor); ASSETS
(client's size); AGE (client's age); CASHFLOW (client's cash-flows from operations); (client's size); AGE (client's age); CASHFLOW (client's cash-flows from operations);
LAGACCR (client's lagged accruals) DEBT (client's debt ratio); GROWTH (client's growth); TENURE (audit firm tenure); CIMPRT (client's importance); EXPERTF (expert audit firm); EXPERTP (expert audit partner); and BIG4 (audit firm type).

As usual in the literature, we complement the analysis us- 
ing discretionary accruals in absolute values with a similar analysis with signed discretionary accruals (e.g. Carey \& Simnett, 2006; Myers et al., 2003). According to Ashbaugh et al. (2003) and Gul et al. (2009) among others, negative discretionary accruals could, in fact, be regarded as a form of conservative accounting. Hence, earnings management through income-decreasing accruals may indicate higher audit quality as it involves stronger accounting conservatism of the auditor. Results of the new estimations, displayed in Table 3, show a negative and significant coefficient of SUBSECTOREXP ( $p$ value $<0.10$ ), and therefore a positive effect of industryspecific experience on audit quality. Besides, as the results of the analysis with accruals in absolute values displayed in Table 2, the remaining variable of interest (CLIENTEXP, SECTOREXP and GENERICEXP) show insignificant results in all cases.

After the estimations we assess whether our results may be affected by potential endogeneity in the model. Chi et al. (2017, p. 383) argue that the negative relationship they report between auditor's experience and discretionary accruals could merely indicate that "partners with longer pre-client experience (more senior partners) audit"better clients" than partners with shorter pre-client experience (younger partners)". The authors finally discard that their results were affected by endogeneity. Similarly, we may also expect endogeneity problems with regard SECTOREXP and above all for GENERICEXP, but not for SUBSECTOREXP. The reason is that, given the generally low number of firms per subsector in the Spanish stock market, each audit firm has just a few clients in each subsector. Moreover, the mandatory rotation of partners after the seventh consecutive year auditing the same client and the fact that audit firms tend to exhaust this seven-year period, minimize the flexibility of the audit firm for assigning the best clients in each subsector to more senior partners. Conversely, when we consider SECTOREXP, and particularly, GENERICEXP, because of the larger number of clients for each audit firm, there are more possibilities that clients are assigned according to the seniority of audit partners. The fact that in the cases when more serious endogeneity problems can be expected, we report insignificant results for both variables suggests that the results for SUBSECTOREXP are not affected by endogeneity.

\subsection{Analysis Conducted with the Auditor's Opinion}

Before the estimations of the logistic model given by Eq. (3), we perform a preliminary univariate analysis of mean and median differences for our variables of interest (CLIENTEXP, SUBSECTOREXP, SECTOREXP and GENERICEXP) by type of opinion in the audit report. Audit reports with MAOs represent, on average, 20 percent of the total reports. ${ }^{3}$ Results of this analysis are shown in Table 4. The $t$-test and the MannWhitney test are used to account for the assessment of significant differences in mean and median values, respectively. Mean and median values do not show large differences depending on the opinion of the audit report. Specifically, we only observe significant differences for GENERICEXP ( $p$-value $<0.05$ with the $t$-test). This result suggests that partners with stronger generic audit experience seem more willing to issue MAOs. Overall, results from this univariate analysis do not suggest a strong impact of partner's audit experience on audit quality as measured by the opinion of the audit report.

Next, we perform the multivariate analysis conducted through logistic estimations of Eq. (3). Results of the es-

${ }^{3}$ This percentage is $7 \%, 8 \%, 10 \%, 20 \%, 19 \%, 22 \%, 30 \%, 35 \%$ and $34 \%$ in the years 2005, 2006, 2007, 2008, 2009, 2010, 2011, 2012 and 2013 respectively.
Table 4

Mean (median) values of the variables measuring experience by type of opinion in the audit report

\begin{tabular}{ccc}
\hline & MAO $=0$ & MAO $=1$ \\
\hline CLIENTEXP & $3.35(3.00)$ & $3.16(3.00)$ \\
SUBSECTOREXP & $1.04(0.00)$ & $1.29(0.00)$ \\
SECTOREXP & $1.13(0.00)$ & $1.15(0.00)$ \\
GENERICEXP & $3.50(1.00)$ & $4.40 * *(2.00)$ \\
\hline
\end{tabular}

Statistical significance at 5\%. The t-test (Mann-Whitney test) is used for the significance analysis of means (medians).

CLIENTEXP (experience of the auditor with the client); SUBSECTOREXP (experience of the auditor in the client's subsector); SECTOREXP (experience of the auditor in the client's sector); GENERICEXP (generic audit experience of the auditor)

timations are shown in Table 5. The log-likelihood ratio test (untabulated) suggest the use of pooled logistic regression over panel data estimations. Therefore, we estimate Eq. (3) with pooled logistic regression and errors clustered at the firm level. All four estimations are globally significant with $39 \%$ pseudo R-squared. The main result in Table 5 is the lack of significant effects for any of the variables measuring auditor experience. Nevertheless, we should note that in all cases the coefficients of our variables of interest present the predicted sign and, in the specific cases of SUBSECTOREXP, the coefficient is not far from being marginally significant ( $p$ value $=0.152$ ). Thus, partner's audit experience does not seem to affect audit quality as measured by the likelihood of a MAO in the audit report. This main result does not provide support for Hypotheses 2 or 3, where both cases advocate a positive effect of experience on audit quality. The only exception occurs for client-specific experience (Hypothesis 1), formulated in the null form. Following the analysis conducted with discretionary accruals in the previous subsection, we expected a positive and significant effect, at least for $S U B$ SECTOREXP. This expectation was also based on the results of Chi \& Chin (2011) showing that clients of industry-specialist auditors are more likely to receive MAOs from their auditors, although Garcia-Blandon \& Argiles-Bosch (2018) do not observe significant differences in the likelihood of audit qualifications between industry-specialist auditors and nonspecialist auditors. Nevertheless, results of the univariate analysis in Table 4 already anticipated the lack of significant effects of industry-specific experience on the opinion of the audit report. Similar to the study conducted with discretionary accruals, results for control variables strongly meet our expectations, as whenever a significant effect is reported (ASSETS, DEBT, PBANK and LAGLOSS), it is always in the predicted direction.

We check the sensitivity of our results to the type of audit qualification. MAOs can be broadly classified into audit qualifications for reasons of going-concern and for other reasons. The different nature of both types of qualifications as well as the different implications for the client (and consequently, for the auditor-client relationship) might justify conducting separate analyses for both types of MAOs. Similar to Chi \& Chin (2011), we perform segmented analyses by type of MAO, differentiating between going-concern MAOs and other types of MAOs. First, for the analysis restricted to going-concern MAOs, Table 6 displays the results of the re-estimations of Eq. (3), after removing from the sample those observations with MAOs for other reasons. The most interesting result is the significant coefficient of SUBSECTOREXP ( $p$-value < 0.01 ) with the predicted positive sign. It indicates that audit partners with stronger industry experience (at the subsector level) are more willing to issue a going-concern MAO to a client which deserves it, thus suggesting stronger independ- 
Table 5

The relationship between auditor experience and the quality of audit services as measured by the likelihood of MAOs. All types of audit qualifications are collectively considered as MAOs

\begin{tabular}{|c|c|c|c|c|c|}
\hline Variable & $\begin{array}{l}\text { Pred. } \\
\text { sign }\end{array}$ & Model 1 & Model 2 & Model 3 & Model 4 \\
\hline CLIENTEXP & ? (H1) & $\begin{array}{l}-0.004 \\
(-0.06)\end{array}$ & & & \\
\hline SUBSECTOREXP & $+(\mathrm{H} 2)$ & & $\begin{array}{l}0.070 \\
(1.43)\end{array}$ & & \\
\hline SECTOREXP & $+(\mathrm{H} 2)$ & & & $\begin{array}{l}0.082 \\
(1.44)\end{array}$ & \\
\hline GENERICEXP & $+(\mathrm{H} 3)$ & & & & $\begin{array}{l}0.035 \\
(1.09)\end{array}$ \\
\hline ASSETS & $+/-$ & $\begin{array}{c}-0.472 \\
(-3.77)^{* * * *}\end{array}$ & $\begin{array}{c}-0.478 \\
(-3.88)^{* * *}\end{array}$ & $\begin{array}{c}-0.482 \\
(-3.65)^{* * * *}\end{array}$ & $\begin{array}{r}-0.487 \\
(-4.02)^{* *}\end{array}$ \\
\hline AGE & - & $\begin{array}{l}0.071 \\
(0.21)\end{array}$ & & & $\begin{array}{l}0.044 \\
(0.13)\end{array}$ \\
\hline DEBT & + & $\begin{array}{c}2.922 \\
(2.09 * *\end{array}$ & $\begin{array}{c}3.099 \\
(2.19) * *\end{array}$ & $\begin{array}{c}2.962 \\
(2.12) * *\end{array}$ & $\begin{array}{c}3.022 \\
(2.12) * *\end{array}$ \\
\hline TENURE & $+/-$ & $\begin{array}{l}-0.203 \\
(-0.75)\end{array}$ & $\begin{array}{l}-0.257 \\
(-1.00)\end{array}$ & $\begin{array}{l}-0.196 \\
(-0.76)\end{array}$ & $\begin{array}{l}-0.180 \\
(-0.68)\end{array}$ \\
\hline CIMPRT & - & $\begin{array}{l}0.147 \\
(0.38)\end{array}$ & & & $\begin{array}{l}159 \\
41)\end{array}$ \\
\hline EXPERTF & + & $\begin{array}{l}0.086 \\
(0.36)\end{array}$ & 9 & $\begin{array}{l}3 \\
4)\end{array}$ & $\begin{array}{l}0.100 \\
(0.42)\end{array}$ \\
\hline EXPERTP & + & $\begin{array}{l}0.472 \\
(1.39)\end{array}$ & $\begin{array}{l}0.478 \\
(1.41)\end{array}$ & $\begin{array}{l}0.490 \\
(1.43)\end{array}$ & $\begin{array}{l}0.501 \\
(1.44)\end{array}$ \\
\hline BIG4 & + & $\begin{array}{l}-0.160 \\
(-0.26)\end{array}$ & $\begin{array}{l}-0.228 \\
(-0.37)\end{array}$ & $\begin{array}{l}-0.275 \\
(-0.47)\end{array}$ & $\begin{array}{l}-0.201 \\
(-0.33)\end{array}$ \\
\hline PBANK & + & $\begin{array}{c}0.670 \\
(3.47)^{* * *}\end{array}$ & $\begin{array}{c}0.648 \\
(3.31)^{* * *}\end{array}$ & $\begin{array}{c}0.681 \\
(3.31)^{* * *}\end{array}$ & $\begin{array}{c}0.659 \\
(3.31)^{* *}\end{array}$ \\
\hline LAGLOSS & + & $\begin{array}{c}0.915 \\
(2.98)^{* * *}\end{array}$ & $\begin{array}{c}0.922 \\
(3.02)^{* * *}\end{array}$ & $\begin{array}{c}0.869 \\
(2.78)^{* * *}\end{array}$ & $\begin{array}{c}0.922 \\
(3.02)^{* *}\end{array}$ \\
\hline LIQUIDITY & - & $\begin{array}{l}-0.127 \\
(-0.40)\end{array}$ & $\begin{array}{l}-0.113 \\
(-0.35)\end{array}$ & $\begin{array}{l}-0.136 \\
(-0.42)\end{array}$ & $\begin{array}{l}-0.116 \\
(-0.36)\end{array}$ \\
\hline Fixed effects & & YES & YES & YES & YES \\
\hline Constant & & $\begin{array}{l}1.977 \\
(1.24)\end{array}$ & $\begin{array}{l}1.770 \\
(1.09)\end{array}$ & $\begin{array}{l}1.946 \\
(1.14)\end{array}$ & $\begin{array}{l}1.989 \\
(1.19)\end{array}$ \\
\hline \# of observations & & 762 & 762 & 762 & 762 \\
\hline Pseudo R-sq. & & 0.39 & 0.39 & 0.39 & 0.39 \\
\hline Wald-Chi sq. & & $158.84 \div * *$ & $161.24 * * *$ & $152.67 * * *$ & $158.31 *$ \\
\hline
\end{tabular}

* , "** , "*** Statistical significance at $10 \%, 5 \%$ and $1 \%$, respectively.

CLIENTEXP (experience of the auditor with the client); SUBSECTOREXP (experience of the auditor in the client's subsector); SECTOREXP (experience of the auditor in the client's sector); GENERICEXP (generic audit experience of the auditor); LAGOPINION (lagged opinion); ASSETS (client's size); AGE (client's age); DEBT LAGOPINION (lagged opinion); ASSETS (client's size); AGE (client's age); DEBT (client's debt ratio); TENURE (audit firm tenure); CIMPRT (client's importance);
EXPERTF (expert audit firm); EXPERTP (expert audit partner); BIG4 (audit firm type); EXPERTF (expert audit firm); EXPERTP (expert audit partner); BIG4 (audit firm type);
PBANK (client's probability of bankruptcy); LAGLOSS (client's lagged loss); and LIQUIDITY (client's liquidity).

ence and higher audit quality. Conversely, for all the remaining definitions of experience, and in particular, for generic audit experience, results are insignificant. It should also be noted the strong explanatory power of the model as shown by Pseudo R-squared values, and the fact that most control variables present significant coefficients.

Subsequently, we perform a similar analysis though restricted to non-going-concern MAOs. Table 7 displays the results of the re-estimations of Eq. (3) after removing from the sample those observations with going-concern MAOs. The most interesting result is the significant effects observed for SUBSECTOREXP and SECTOREXP ( $p$-value $<0.10)$, in both cases with the predicted positive sign. This indicates a higher propensity to issue non-going-concern MAOs (higher-quality audit services) by those auditors with stronger industryspecific experience, no matter whether industries are defined at the sector of subsector levels. It should be noted, that compared to the former analysis conducted with going-concern MAOs, both the explanatory power of the proposed model and the number of control variables with statistically significant coefficients are considerably lower.

Consistent with the results of the analysis conducted with

\section{Table 6}

The relationship between auditor experience and the quality of audit services as measured by the likelihood of going-concern MAOs

\begin{tabular}{ccccc}
\hline Variable & Model 1 & Model 2 & Model 3 & Model 4 \\
\hline CLIENTEXP & 0.105 & & & \\
& $(0.88)$ & & &
\end{tabular}

SUBSECTOREXP

SECTOREXP

GENERICEXP

ASSETS

AGE

DEBT

TENURE

CIMPRT

EXPERTF

EXPERTP

BIG4

PBANK

LAGLOSS

LIQUIDITY

Fixed effects

Constant

\# of observations

Pseudo R-sq.

Wald-Chi sq.

$$
\text { Statistical }
$$

CLIENTEXP (experience of the auditor with the client); SUBSECTOREXP (experience of the auditor in the client's subsector); SECTOREXP (experience of the auditor in the client's sector); GENERICEXP (generic audit experience of the auditor); LAGOPINION (lagged opinion); ASSETS (client's size); AGE (client's age); DEBT (client's debt ratio); TENURE (audit firm tenure); CIMPRT (client's importance); EXPERTF (expert audit firm); EXPERTP (expert audit partner); BIG4 (audit firm type); PBANK (client's probability of bankruptcy); LAGLOSS (client's lagged loss); and LIQUIDITY (client's liquidity).

discretionary accruals as the measure of audit quality depicted in Tables 2 and 3, the figures displayed in Tables 6 and 7 also indicate that industry-specific audit experience is the only type of audit experience that seems to matter in terms of audit quality. It may seem surprising that when all types of MAOs are jointly considered, the coefficient of SUBSECTOREXP is insignificant, whereas in both segmented analyses by type of MAO, SUBSECTOREXP present significant coefficients in all cases. We understand that these differences are explained by the different drivers of going-concern and nongoing-concern MAOs. We base this view on the differences in both the explanatory power of the estimations (Pseudo $R$-squared is 75 percent in the model restricted to goingconcern MAO and only 28 percent in the model with nongoing-concern MAO), and in the number of control variables with significant coefficients (up to nine in the model with going-concern MAO versus only three in the model with nongoing-concern MAO). This indicates that model displayed by 
Eq. (3) is more suitable to explain the auditor's decision to issue a going-concern MAO than other types of MAOs.

Table 7

The relationship between auditor experience and the quality of audit services as measured by the likelihood of non-going-concern MAOs

\begin{tabular}{|c|c|c|c|c|}
\hline Variable & Model 1 & Model 2 & Model 3 & Model 4 \\
\hline CLIENTEXP & $\begin{array}{l}0.017 \\
(0.23)\end{array}$ & & & \\
\hline SUBSECTOREXP & & $\begin{array}{c}0.088 \\
(1.73) *\end{array}$ & & \\
\hline SECTOREXP & & & $\begin{array}{c}0.099 \\
(1.72)^{*}\end{array}$ & \\
\hline GENERICEXP & & & & $\begin{array}{l}0.038 \\
(1.13)\end{array}$ \\
\hline ASSETS & $\begin{array}{c}-0.369 \\
(-2.96)^{* * * *}\end{array}$ & $\begin{array}{c}-0.369 \\
(-2.97)^{* * *}\end{array}$ & $\begin{array}{c}-0.379 \\
(-2.87)^{* * *}\end{array}$ & $\begin{array}{c}-0.387 \\
(-3.17)^{* * *}\end{array}$ \\
\hline AGE & $\begin{array}{l}0.180 \\
(0.48)\end{array}$ & $\begin{array}{l}0.275 \\
(0.75)\end{array}$ & $\begin{array}{l}0.187 \\
(0.51)\end{array}$ & $\begin{array}{l}0.146 \\
(0.39)\end{array}$ \\
\hline DEBT & $\begin{array}{l}1.451 \\
(1.01)\end{array}$ & $\begin{array}{l}1.591 \\
(1.10)\end{array}$ & $\begin{array}{l}1.398 \\
(0.98)\end{array}$ & $\begin{array}{l}1.525 \\
(1.03)\end{array}$ \\
\hline TENURE & $\begin{array}{l}-0.245 \\
(-0.95)\end{array}$ & $\begin{array}{l}-0.299 \\
(-1.25)\end{array}$ & $\begin{array}{l}-0.222 \\
(-0.92)\end{array}$ & $\begin{array}{l}-0.208 \\
(-0.84)\end{array}$ \\
\hline CIMPRT & $\begin{array}{l}0.071 \\
(0.15)\end{array}$ & & $\begin{array}{l}0.117 \\
(0.25)\end{array}$ & $\begin{array}{l}0.096 \\
(0.20)\end{array}$ \\
\hline EXPERTF & $\begin{array}{l}0.125 \\
(0.49)\end{array}$ & $\begin{array}{l}0.083 \\
(0.32)\end{array}$ & $\begin{array}{l}0.127 \\
(0.50)\end{array}$ & $\begin{array}{l}0.120 \\
(0.47)\end{array}$ \\
\hline EXPERTP & $\begin{array}{l}0.180 \\
(0.45)\end{array}$ & $\begin{array}{l}0.184 \\
(0.46)\end{array}$ & $\begin{array}{l}0.195 \\
(0.48)\end{array}$ & $\begin{array}{l}0.223 \\
(0.54)\end{array}$ \\
\hline BIG4 & $\begin{array}{l}-0.316 \\
(-0.50)\end{array}$ & $\begin{array}{l}-0.408 \\
(-0.54)\end{array}$ & $\begin{array}{l}-0.449 \\
(-0.73)\end{array}$ & $\begin{array}{l}-0.374 \\
(-0.59)\end{array}$ \\
\hline PBANK & $\begin{array}{c}0.628 \\
(3.28)^{* * *}\end{array}$ & $\begin{array}{c}0.596 \\
(3.09)^{* \cdots *}\end{array}$ & $\begin{array}{c}0.651 \\
(3.07)^{* * *}\end{array}$ & $\begin{array}{c}0.616 \\
(3.09)^{* \cdots *}\end{array}$ \\
\hline LAGLOSS & $\begin{array}{c}0.823 \\
(2.29)^{* *}\end{array}$ & $\begin{array}{c}0.835 \\
(2.28)^{* * *}\end{array}$ & $\begin{array}{c}0.760 \\
(2.09) * *\end{array}$ & $\begin{array}{c}0.840 \\
(2.32)^{* *}\end{array}$ \\
\hline LIQUIDITY & $\begin{array}{l}-0.068 \\
(-0.17)\end{array}$ & $\begin{array}{l}-0.041 \\
(-0.10)\end{array}$ & $\begin{array}{l}-0.076 \\
(-0.19)\end{array}$ & $\begin{array}{l}-0.060 \\
(-0.15)\end{array}$ \\
\hline Fixed effects & YES & YES & YES & YES \\
\hline Constant & $\begin{array}{l}2.000 \\
(1.07)\end{array}$ & $\begin{array}{l}1.742 \\
(0.90)\end{array}$ & $\begin{array}{l}2.085 \\
(1.03)\end{array}$ & $\begin{array}{l}2.097 \\
(1.06)\end{array}$ \\
\hline $\mathrm{N}$ & 712 & 712 & 712 & 712 \\
\hline Pseudo R-sq. & 0.27 & 0.28 & 0.28 & 0.28 \\
\hline Wald-Chi sq. & $120.40 * * *$ & $125.78 * * *$ & $119.31 * * *$ & $118.99 * * *$ \\
\hline
\end{tabular}

CLIENTEXP (experience of the auditor with the client); SUBSECTOREXP (experience of the auditor in the client's subsector); SECTOREXP (experience of the auditor in the client's sector); GENERICEXP (generic audit experience of the auditor); (CAOPINON (lagged opinion); ASSETS (client's size); AGE (client's age); DEBT (CXPRRT (exp EXPERTF (expert audit firm); EXPERTP (expert audit partner); BIG4 (audit firm type); PBANK (client's probability of bankruptcy); LAGLOSS (client's lagged loss); and LIQUIDITY (client's liquidity).

\section{Conclusions, implications and limitations}

Through this study, we have investigated how the audit experience of individual auditors contributes to the quality of the audit services. Since experience constitutes a main driver of expertise, highly-experienced auditors are expected to provide higher-quality audit services. The results of the study indicate that there exists a positive and significant relationship between the industry-specific experience of individual auditors and the quality of audit services. Furthermore, the results show that neither the client-specific experience nor the generic audit experience of audit partners significantly contribute to audit quality. Both results can be regarded as considerable robust. The first one holds in the two analyses conducted with discretionary accruals as the measure of audit quality, no matter if accruals are computed in absolute or signed values, as well as in both segmented analyses using the opinion of the audit report as the indicator of audit quality. With regard the lack of a significant relationship between either client-specific experience or generic audit experience and audit quality, this result holds, with no exception, in all the analyses conducted through this study.

A straightforward practical implication of these two findings is that, in order to provide higher-quality audit services, audit firms should encourage the industry specialisation of individual auditors. It should be noted that, according to the results of this study, the generic audit experience of the audit partner is irrelevant in terms of its potential contribution to audit quality. Therefore, an eventual reinforcement of the industry specialization of individual auditors within the audit firm would likely result, not only in lower audit costs for the audit firm, but also in higher levels of audit quality. Due to the fact that small audit firms have less possibilities for implementing industry specialization strategies of their audit partners, they would likely be in a worse situation to compete in terms of audit quality with Big 4 audit firms. At a more theoretical level, the results of this study also indicate that taking into account the whole audit career of the individual auditor seem to provide a more accurate indicator of his/her audit expertise than just considering the level of specialization of these auditors.

Even though this study is conducted with a sample of Spanish companies, following Chi et al. (2017) argument, our results might be of interest more broadly; not only because the issues investigated here (audit quality and partner audit experience) are universal issues in the auditing literature, but also because the structure of the audit market (i.e. strong concentration by Big 4 audit firms), the audit process and the use of financial statements by market participants are similar in Spain and in many developed and emerging countries (particularly in the context of comparisons with other EU countries).

The research presented in this study is subject to several limitations. First, although the proxies employed to capture the quality of audit services are consistent with the prior literature, they do not give us a detailed understanding about the internal processes which make up an audit and the impact this has on the quality of audit services. We acknowledge the need to develop more accurate and specific indicators that take into account the internal processes which occur within the audit firm. Secondly, although we intended to collect information about partners' entire careers as signing auditors, data was only available from 1995 onwards. Therefore, any audit experience of the individual auditor acquired before this year has not been considered.

\section{Funding}

This study has received no funding.

\section{Acknowledgements}

We thank the participants at the XI Workshop on Empirical Research in Financial Accounting and, in particular Araceli Mora as the discussant of a former version of this paper for helpful comments and suggestions.

\section{Conflict of interests}

The authors report no conflict of interest. 


\section{References}

Ackerman, P. L. (1987). Individual differences in skill learning: An integration of psychometric and information processing perspectives. Psychological Bulletin, 102, 327.

Anthony, J. H., \& Ramesh, K. (1992). Association between accounting performance measures and stock prices. Journal of Accounting and Economics, 15(2-3), 203-227. https://doi. org/10.1016/0165-4101(92)90018-W

Ashbaugh, H., LaFond, R., \& Mayhew, B.W. (2003). Do nonaudit services compromise auditor independence? Further evidence. The Accounting Review, 78(3), 611-639. https: //doi.org/10.2308/accr.2003.78.3.611

Becker, C. L., DeFond, M. L., Jiambalvo J. J., \& Subramanyam, K. R. (1998). The effect of audit quality on earnings management. Contemporary Accounting Research, 15(1), 124. https://doi.org/10.1111/j.1911-3846.1998.tb00547.x

Bedard, J. (2012). Discussion of "Audit partner specialization and audit fees: Some evidence from Sweden". Contemporary Accounting Research, 29(1), 341-348. https://doi. org/10.1111/j.1911-3846.2011.01153.x

Carcello, J. V., Hermanson, D. R., \& Fuss, H. F. (1995). Temporal changes in bankruptcy-related reporting. AUDITING: A Journal of Practice \& Theory, 14(2), 133-143.

Carcello, J.V. \& Nagy, A.L. (2004). Client size, auditor specialization and fraudulent financial reporting. Managerial Auditing Journal, 19(5), pp. 651-668.

Carey, P., \& Simnett, R. (2006). Audit partner tenure and audit quality. The Accounting Review, 81(3), 653-676. https: //doi.org/10.2308/accr.2006.81.3.653

Chen, C. Y., Lin, C. J., \& Lin, Y. C. (2008). Audit partner tenure, audit firm tenure, and discretionary accruals: Does long auditor tenure impair earnings quality? Contemporary Accounting Research, 25(2), 415-445. https://doi.org/10. 1506/car.25.2.5

Chi, H. Y., \& Chin, C. L. (2011). Firm versus partner measures of auditor industry expertise and effects on auditor quality. AUDITING: A Journal of Practice \& Theory, 30(2), 201229. https://doi.org/10.2308/ajpt-50004

Chi, M. T. H., Glaser, R., \& Rees, E. (1982). Expertise in problem solving. In R. Sternberg, (Ed). Advances in the Psychology of Human Intelligence (pp. 7-75). Hillsdale, NJ: Erlbaum.

Chi, W., \& Huang, H. (2005). Discretionary accruals, audit-firm tenure and audit-partner tenure: Empirical evidence from Taiwan. Journal of Contemporary Accounting and Economics, 1(1), 65-92. https://doi.org/10.1016/ S1815-5669(10)70003-5

Chi, W., Myers, L. A., Omer, T. C., \& Xie, H. (2017). The effects of audit partner pre-client and client-specific experience on audit quality and on perceptions of audit quality. Review of Accounting Studies, 22(1), 361-391. https://link.springer. com/article/10.1007/s11142-016-9376-9

Chin, C. L., \& Chi, H. Y. (2009). Reducing restatements with increased industry expertise. Contemporary Accounting Research, 26(3), 729-765. https://doi.org/10.1506/car.26. 3.4

Cohen, W. M., \& Levinthal, D. A. (1990). Absorptive capacity: A new perspective on learning and innovation. Administrative Science Quarterly, 35(1), 128-152. https://www.jstor. org/stable/2393553

DeAngelo, L. E. (1981). Auditor size and audit quality. Journal of Accounting and Economics, 3(3), 183-199. https: //doi.org/10.1016/0165-4101(81)90002-1

Dechow, P. M., Sloan, R. G. \& Sweeney, A. P. (1995). Detecting earnings management. The Accounting Review, 70(2),
193-225. https://www.jstor.org/stable/248303

Ellis, H. (1965 New York The Transfer of Learning. New York: Macmillan Company.

Ericsson, K. A., Krampe, R. T., \& Tesch-Römer, C. (1993). The role of deliberate practice in the acquisition of expert performance. Psychological Review, 100(3), 363-406.

Fargher, N., Lee, H., \& Mande, V. (2008). The effect of audit partner tenure on client managers' accounting discretion. Managerial Auditing Journal, 23(2), 161-186. https: //doi.org/10.1108/02686900810839857

Ferguson, A., Francis, J. R., \& Stokes, D. J. (2003). The effects of firm-wide and office-level industry expertise on audit pricing. The Accounting Review, 78(2), 429-448. https: //doi.org/10.2308/accr.2003.78.2.429

Fisher, M. L., \& Ittner, C. D. (1999). The impact of product variety on automobile assembly operations: Empirical evidence and simulation analysis. Management Science, 45(6), 771-786. https://doi.org/10.1287/mnsc.45.6.771

Francis, J. R., Maydew, E. L., \& Sparks, H. C. (1999). The role of Big 6 auditors in the credible reporting of accruals. AUDITING: A Journal of Practice \& Theory, 18(2), 17-34. https://doi.org/10.2308/aud.1999.18.2.17

Francis, J. R., \& Wang, D. (2008). The joint effect of investor protection and big 4 audits on earnings quality around the world. Contemporary Accounting Research, 25(1), 157191. https://doi.org/10.1506/car.25.1.6

Frankel, R. M., Johnson, M. F., \& Nelson, K. K. (2002). The relation between auditors' fees for nonaudit services and earnings management. The Accounting Review, 77(s-1), 71105. https://doi.org/10.2308/accr.2002.77.s-1.71

Frensch, P. A., \& Sternberg, R. J. (1989). Expertise and intelligent thinking: When is it worse to know better? In R. J. Sternberg (Ed.), Advances in the Psychology of Human Intelligence (pp. 157-188). Hillsdale, NJ: Erlbaum.

Garcia-Blandon, J., \& Argiles-Bosch, J. M. (2017). The interaction effects of firm and partner tenure on audit quality. Accounting and Business Research, 47(7), 810-830. https: //doi.org/10.1080/00014788.2017.1289073

Garcia-Blandon, J., \& ArgilesBosch, J. M. (2018). Audit partner industry specialization and audit quality: Evidence from Spain. International Journal of Auditing, 22(1), 98-108. https://doi.org/10.1111/ijau.12107

Glaser, R., \& Chi, M. T. H. (1988). Overview. In M. T. H. Chi, R. Glaser, \& M. J. Farr, (Eds.), The Nature of Expertise (pp. xv-xxviii). Hillsdale, NJ: Erlbaum.

Goodwin, J., \& Wu, D. (2014). Is the effect of industry expertise on audit pricing an office-level or a partner-level phenomenon? Review of Accounting Studies, 19(4), 1532-1578. https://link.springer.com/article/10. 1007/s11142-014-9285-8

Gul, F. A., Fung, S. Y. K., \& Jaggi, B. (2009). Earnings quality: Some evidence on the role of auditor tenure and auditors' industry expertise. Journal of Accounting and Economics, 47(3), 265-287. https://doi.org/10.1016/j.jacceco. 2009.03.001

Gul, F. A., Wu, D., \& Yang, Z. (2013). Do individual auditors affect audit quality? Evidence from archival data. The Accounting Review, 88(6), 1993-2023. https://doi.org/10. 2308/accr-50536

Healy, P. (1996). Discussion of a market-based evaluation of discretionary accrual models. Journal of Accounting Research, 34(supplement), 107-115. https://www.jstor.org/ stable/2491428

Ittonen, K., Johnstone, K., \& Myllymäki, E. R. (2015). Audit partner public-client specialisation and client abnormal accruals. European Accounting Review, 24(3), 607-633. 
https://doi.org/10.1080/09638180.2014.906315

Johnson, V. E., Khurana, I. K., \& Reynolds, J. K. (2002). Audit-firm tenure and the quality of financial reports. Contemporary Accounting Research, 19(4), 637-660. https://doi. org/10.1506/LLTH-JXQV-8CEW-8MXD

Jones, J. J. (1991). Earnings management during import relief investigation. Journal of Accounting Research, 29(2), 193-228. https://www.jstor.org/stable/2491047

Knechel, W. R. (2000). Behavioral research in auditing and its impact on audit education. Issues in Accounting Education, 15(4), 695-712. https://doi.org/10.2308/iace.2000. 15.4.695

Knechel, W. R., Vanstraelen, A., \& Zerni, M. (2015). Does the identity of engagement partners matter? An analysis of audit partner reporting decisions. Contemporary Accounting Research, 32(4), 1443-1478. https://doi.org/10.1111/ 1911-3846.12113

Kwon, S. Y., Lim, C. Y., \& Tan, P. M. S. (2007). Legal systems and earnings quality: The role of auditor industry specialization. Auditing: A Journal of Practice \& Theory, 26(2), 25-55. https://doi.org/10.2308/aud.2007.26.2.25

Lapre, M. A., Mukherjee, A. S., \& Van Wassenhove, L.N. (2000). Behind the learning curve: Linking learning activities to waste reduction. Management Science, 46(5), 597-611. https://doi.org/10.1287/mnsc.46.5.597.12049

Libby, R., \& Luft, J. (1993). Determinants of judgment performance in accounting settings: ability, knowledge, motivation, and environment. Accounting, Organizations and Society, 18(5), 425-450. https://doi.org/10.1016/ 0361-3682(93)90040-D

Lys, T., \& Watts, R. L. (1994). Lawsuits against auditors. Journal of Accounting Research, 32(supplement), 65-93. https://www.jstor.org/stable/2491440

Manry, D. L., Mock, T. J., \& Turner, J. L. (2008). Does increased audit partner tenure reduce audit quality? Journal of Accounting, Auditing \& Finance, 23(4), 553-572. https: //doi.org/10.1177/0148558X0802300406

Mautz, R. K. \& Sharaf, H. A. (1961). The Philosophy of Auditing. American Accounting Association.

Myers, J. N., Myers, L. A., \& Omer, T. C. (2003). Exploring the term of the auditor-client relationship and the quality of earnings: A case for mandatory auditor rotation? The Accounting Review, 78(3), 779-799. https://doi.org/10.2308/ accr.2003.78.3.779

Mora, A., \& Sabater, A. (2008). Evidence of incomedecreasing earnings management before labor negotiations within firms. Investigaciones Economicas, 32, 201-230. https: //www.redalyc.org/html/173/17332203/

Nagy, A. L. (2014). Audit partner specialization and audit fees. Managerial Auditing Journal, 29(6), 513-526. https: //doi.org/10.1108/MAJ-11-2013-0966

Numan, W., \& Willekens, M. (2012). An empirical test of spatial competition in the audit market. Journal of Accounting and Economics, 53(1), 450-465. https://doi.org/ 10.1016/j.jacceco.2011.10.002

Patel, V. L., \& Groen, G. J. (1991). The general and specific nature of medical expertise: A critical look. In K. A. Ericsson \& J. Smith (Eds.), Toward a General Theory of Expertise (pp. 93-125). Cambridge, England: Cambridge University Press.

Reid, C. D., \& Youngman, J. F. (2017). New audit partner identification rules may offer opportunities and benefits. Business Horizons, 60(4), 507-518. https://doi.org/10. 1016/j.bushor.2017.03.008

Schilling, M. A., Vidal, P., Ployhart, R. E., \& Marangoni, A. (2003). Learning by doing something else: Variation, related- ness, and the learning curve. Management Science, 49(1), 3956. https://doi.org/10.1287/mnsc.49.1.39.12750

Shu, S. (2000). Auditor resignations: clientele effects and legal liability. Journal of Accounting and Economics, 29(2), 173-205. https://doi.org/10.1016/S0165-4101(00) 00019-7

Sloan, R. (1996). Do stock prices fully reflect information in accruals and cash flows about future earnings? The Accounting Review, 71(3), 289-315. https://www.jstor.org/ stable/248290

Sonu, C. H., Choi, A., Lee, J., \& Ha, W. (2016). Audit partner's length of audit experience and audit quality: evidence from Korea. Asia-Pacific Journal of Accounting \& Economics, forthcoming. https://doi.org/10.1080/16081625.2016. 1242428

Wang, X., Wang, Y., Yu, L., Zhao, Y., \& Zhang, Z. (2015). Engagement audit partner experience and audit quality. China Journal of Accounting Studies, 3(3), 230-253. https: //doi.org/10.1080/21697213.2015.1055776

Watts, R. L., \& Zimmerman, J. L. (1986). Positive Accounting Theory. Prentice Hall International.

Ye, P., Carson, E., \& Simnett, R. (2011). Threats to auditor independence: The impact of relationship and economic bonds. AUDITING: A Journal of Practice \& Theory, 30(1), 121148. https://doi.org/10.2308/aud.2011.30.1.121

Zerni, M. (2012). Audit partner specialization and audit fees: Some evidence from Sweden. Contemporary Accounting Research, 29(1), 312-340. https://doi.org/10.1111/j. 1911-3846.2011.01098.x

Zmijewski, M. E. (1984). Methodological issues related to the estimation of financial distress prediction models. Journal of Accounting Research, 22(supplement), 59-82. https://www.jstor.org/stable/2490859 